\title{
Editorial: The future of environmental geotechnics: creating the new value proposition
}

\section{Craig H. Benson}

Dean of Engineering, University of Virginia, Charlottesville, VA, USA

(chbenson@virginia.edu)

The discipline of environmental geotechnics has evolved since its incarnation in the late 1970 s to early 1980 s. I was fortunate to take one of the first courses on the subject in 1984 as an undergraduate student under the tutelage of Dr Jeffrey Evans, at the time an adjunct professor and $\mathrm{PhD}$ student at Lehigh University. Today the discipline is mature - curricula are rich in courseware, research programmes are commonplace, and employment is widespread across engineering firms around the globe. The faculty group I was part of at the University of Wisconsin-Madison for many years had five different specialty courses in environmental geotechnics, and a cadre of supporting courses in geotechnical engineering, environmental engineering and environmental chemistry.

The maturing of the profession necessitates that we begin to think about the future and, going forward, how we must create a compelling value proposition for our clients and for society. To understand the need for change, we need to look back on how and why the discipline formed.

In North America, at least, the 1960s and 1970s were fraught with prominent environmental problems (in some cases catastrophes, like Love Canal (New York); Times Beach (Missouri); and the flaming Cuyahoga River in Cleveland (Ohio)). Environmental protection was modest at best, and examples of poor environmental stewardship were commonplace. I remember this clearly as a boy when our family would travel from our residence in the industrial Lehigh Valley of Pennsylvania to our vacation home in the beautiful Pocono Mountains. On that trip we passed by a zinc smelter with not a living item within a kilometre - not a tree, a flower or blade of grass. I remember those days as a boy, and our regular trips past the smelter. That image is imprinted permanently in my memory and is the basis for the career that I followed. Today, that smelter is recorded as one of the most well-known Superfund projects in US history (USC, 1980).

The health impacts of facilities and contaminated locations like these were presenting themselves in terrible ways. The public was outraged and demanding that the government step in to protect the people. A conservative Republican President of the United States, Richard Nixon, created an enormous federal agency to address this problem by Executive Order - a stroke of a pen without the need for Congressional approval - which indicates the urgency that was needed to address the problem. New rules and regulations were passed that industry had to follow or face severe penalties. New technological requirements were imposed by regulation, without the technology even being available (in the USA, think of the Hazardous and Solid Waste Amendments to the Resource Conservation and Recovery Act of 1984 (USC, 1984)). Our discipline was born, and what a great time to be an engineer or a researcher! Industry and the public needed engineers to solve these vexing problems, engineers with the appropriate skills were in short supply, and research support to develop the technology required by regulation was flowing!

Over the next three decades, this initial impetus drove the monumental growth of the discipline, both the legions of engineers in practise today and a treasure chest of technology. In some areas (e.g. landfill liners), the discipline has been so successful that it nearly drove itself out of business! These accomplishments are wonderful, but a maturing discipline presents problems not present during the years of rapid growth and development. A mature discipline has accepted technologies and a large and diversified workforce to solve problems. The days are over when the engineer can set the price for technology or solutions needed by industry that are on the debit side of the balance sheet for most clients - the bane of being a mature environmental business. The unfortunate consequence is commoditisation, which drives down innovation and financial rewards.

This new environment means that we need to re-think our profession and focus on issues that move our discipline from the debit side to the credit side of our clients' balance sheet. Solutions that reduce cost to our clients are not enough, as they will never move the profession from debit to credit. We need to create a new value proposition. We need to develop technology and create solutions that provide revenue creation for our clients.

The climate, energy and natural resource challenges facing our society present this opportunity for the profession. As climate change policies develop, and carbon control becomes required around the globe, global markets with economic power will develop. These markets will provide an opportunity for our clients to develop and/or use technologies that save carbon and provide a commodity to sell (e.g. carbon credits sold on a carbon exchange). A similar phenomenon is likely to occur in the energy arena. While 
we are currently in a state of over supply in some energy sectors, the projections for growth in energy consumption indicate that consumption will far out-strip energy supply in the future, creating energy constraints that drive up energy costs and create markets for new solutions. For example, data centres currently consume $1.5 \%$ of all energy consumption globally. Growth of the 'internet of things' is expected to increase this percentage by $10 \times$ - that alone is game changing. At some point, energy policy will also create a global market for energy credits. Markets for natural resources (e.g. metals, minerals) will also be constrained again as economies in the developing world grow, providing an opportunity to repurpose materials into a high-priced commodity marketplace.

These are great opportunities in environmental geotechnics that can create compelling value because they move the profession from the debit side to the credit side of the balance sheet for clients. For example, the engineer who is able to repurpose a waste stream into a valuable construction commodity will win rewards from their clients. Transforming a waste with a cost and liability for disposal into a byproduct commodity for industry (e.g. an alternative construction material for roadways, a new feedstock for cement) eliminates disposal costs and creates revenue for the client. A lifecycle analysis could also show that using this alternative material reduces carbon emissions and is deserving of carbon and energy credits that a client can trade on a carbon exchange, creating more revenue. The engineer who is able to re-think managing a municipal solid waste stream in terms of sustainable materials management will reap similar rewards. Organic waste can be used to create carbon-neutral energy; metals, plastics, and other resources extracted from the waste stream will be processed and sold on commodities markets as feedstock; and energy and carbon savings will be sold as credits in a global market.

The time for a new vision of environmental geotechnics is in front of us. A new focus is needed on technologies and solutions that create a compelling value proposition for our clients. This mindset for the future is fundamentally different for an industry that has roots in an era when demand for technology and services was high, knowledge and human resources were in short supply, and rewards were plentiful. This is a mindset in which innovation and creativity thrive, opportunities are abundant, and rewards are plentiful. This future is bright for those who reach out and grasp it!

\section{REFERENCES}

USC (United States Congress) (1980) Comprehensive

Environmental Response, Compensation, and Liability Act of 1980, Public Law 96-510, 94 STAT. 2767, 96th Congress, December 3, 1980, United States Congress, Washington, DC, USA.

USC (1984) Hazardous and Solid Wastes Amendments of 1984, Public Law 98-616, 98 STAT. 3224, 98th Congress, November 8, 1984, United States Congress, Washington, DC, USA. 